\title{
Method of gearbox state estimation of the metro tunnel escalator drive
}

\author{
Yu. M. Danylchenko ${ }^{1} \bullet$ V. Yu. Bojko² $\bullet$ A. I. Petryshyn ${ }^{1}$ \\ ${ }^{1}$ Igor Sikorsky Kyiv Polytechnic Institute", Kyiv, Ukraine; \\ 2 Progresstech-Ukraine, Kyiv, Ukraine
}

\begin{abstract}
A method for detecting excitations leading to the damage of the gears and bearings working surfaces has been developed by means of experimental study of the dynamic characteristics of the gearbox of metro tunnel escalator drive in normal and bad performance. The technique is based on the acquisition and analysis of low and high resolution spectra. The technique is tested during the analysis of vibration spectra of a standard three-stage, four-shaft gearbox of tunnel escalator drive. The vibration analysis was performed using the kinematic excitation frequencies generated by the gears and rolling bearings in the zones of resonance vibrations of the gearbox elements. According to the results of the analysis, the presence of variable stiffness of the teeth in one of the gears and damage of the inner ring of the ball bearing of the intermediate shaft cover is established.

Keywords: gearbox, vibration spectrum, fault diagnosis, DASYLab, low and high resolution spectra, natural frequencies, vibration modes
\end{abstract}

\section{Introduction}

Modern systems of the machines technical state monitoring are increasingly using diagnostic methods not only to identify defects, but also to identify the causes of changes in the machines performance during their life cycle [1]. This combination of monitoring and diagnostics helps to improve the quality control of machines and to accurately predict their operable time. The problem of ensuring the machines operable condition is particularly relevant for the subway transportation system, because it determines the safety of passengers and the continuity of passenger traffic. First and foremost, it concerns tunnel escalators, because their capacity largely determines the efficiency of the entire subway.

The technical state of the rotary machines, as well as the change in the parameters of the friction coupling elements contact surfaces (bearings, current transmissions, gears, etc.) is largely determined by the external (resulting from operational process) and internal (resulting from the coupling contact) vibration loads. In this case, the mechanical vibrations that occur in the rotary machine are not only a source of coupling elements contact surfaces defects appearance and development, but also a tool for their detection.

The performance of the gearbox of metro tunnel escalator drive is characterized by considerable loads, including those of dynamic nature. Thus, due to the gears production and assembly errors, as well as the cyclic contact interaction of the gear wheels teeth during operation, a series of shock pulses occur [2]. These pulses in a normal performance gearbox have a low-amplitude, broadband nature, and in the spectrum of the vibration signal presented as peaks and humps of "white noise", located in the gearbox elements local resonance areas. The reason is the limit of the level of energy generated by the initial defects of the gearbox elements. But over time, under heavy loads, the action of shock pulses causes defects such as influxes, detachments, and chips that develop extremely fast and can cause the gearbox to wear out.

Similar shock pulse series can be also caused by the gearbox shafts rolling bearings [3]. The vibration signal of the faulty rolling bearing includes deterministic signals, bearing elements defects signals and noise [4]. Deterministic 
signals are usually low-frequency signals of manufacturing errors of bearings tracks and rolling bodies. Defects signals (chips on the working surfaces of the tracks and rolling bodies) of the bearing are the periodic resonance vibrations of the bearing structure elements resulting from short impulses generated each time the defect enters the contact zone of the coupled bearing elements [3]. It is this difference in signals that distinguishes signals from defects in the bearing elements from the common signal. This difference also determines the effectiveness of the methods of condition monitoring and diagnostics of rolling bearing faults [5].

The vibration spectrum of a defectless gearbox usually contains harmonics caused by the kinematics of the gears and the shaft support bearings.

In the vibration spectrum of the N-stage gearbox, $\mathrm{N}$ series of harmonics corresponding to the shaft speed and $(\mathrm{N}-1)$ series of harmonics with gear frequencies will be observed. Typical for the rolling bearings of each gearbox shaft will be the harmonics corresponding to the speed of the shaft and its multiple frequencies (usually, the 2nd and 3rd harmonics of the rotation frequency), as well as the separator speed, the inner and outer race frequencies, the ball spin frequency, as well as multiples of their frequency $[6,7]$.

The appearance and development of defects on the working surfaces of the gears and bearings lead to significant changes in the initial vibration spectra, but can be presented somewhat differently. Thus, defects of the working surfaces of the gears are mostly manifested in the low- and mid-frequency range of the vibration spectrum (in the mode of vibration acceleration measurement), and the defects of the bearings in the mid- and high-frequency range of the spectrum [7, 8]. This is in particular associated with the use of high frequency resonance technique (HFRT) and shock pulse method (SPM) [5] for the diagnostics of bearings defects. The use of low-frequency excitation to detect defects in the elements of low-speed bearings is deemed virtually impossible. The main reason for this is the limit on the level of energy generated by defects in the bearing elements [8].

Current methods of diagnosis of bearing defects are usually based on the use of different analog signals filtering methods $[4,5]$. These methods are implemented by means of virtual instruments (Virtual Instrumentation), the most famous of which are LabVIEW from National Instruments (USA) and DASYLab from DATALOG GmbH (Germany) $[9,10]$.

LabVIEW (Laboratory Virtual Instrument Engineering Workbench) is a graphical application programming environment that is used as a standard tool for measuring, analyzing data and further managing devices and study objects. LabVIEW is a high-level environment and is used not only in data acquisition and processing systems, but also for the management of technical facilities and processes.

DASYLab (Data Acquisition Systems Laboratory) is a software package for data acquisition systems with all types of interfaces to connect to hardware such as RS232, IEEE USB, parallel port, ISA bus, PCI bus, and more. Moreover, DASYLab has many functional modules for measurement and control.

A great practical advantage of DASYLab is the ability to use an audio card for the input / output of analog AC signals (with some sampling frequency limitations) and a parallel PC port for digital I / O. This function is performed by a special driver in the system that provides real-time operation. This DASYLab property allows you to get extremely cheap solutions in terms of hardware costs for a wide range of measurement and testing tasks, including vibration and noise of rotary machines.

The purpose of the study comprises the development of express method for the online monitoring of the metro tunnel escalator drive gearbox performance for use in the metro escalator service system of technical state monitoring.

\section{Object and prerequisites of the study}

The study object is the ET-2 type tunnel escalator drive gearbox of Kyiv metro, fig. 1.

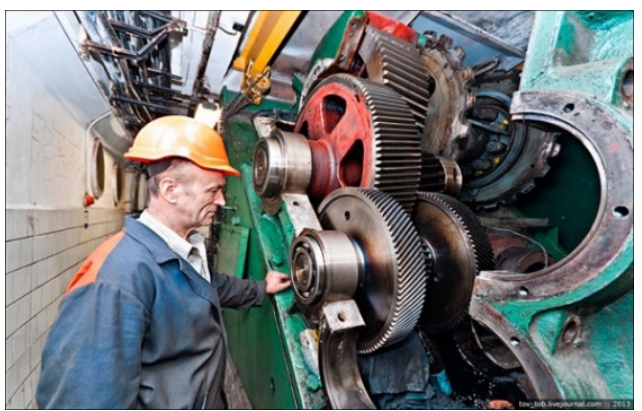

$a$

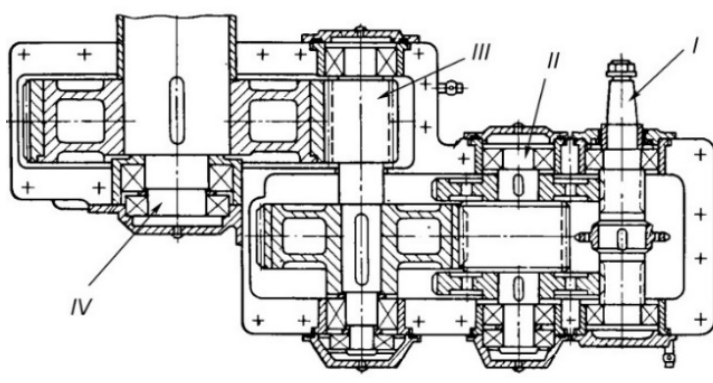

$b$

Fig. 1. ET-2 type tunnel escalator drive gearbox: $a$ ) photo [11]; $b$ ) construction scheme [12] 
The gearbox is three-stage, contains four shafts. Shafts are installed in the gearbox housing with the rolling bearings as supports [12]. The kinematic scheme of the gearbox is depicted on fig. 2.

The vibration signal measurement was performed by means of vibration acceleration sensor PCB $353 \mathrm{~B} 15$ that is installed on the II (intermediate) shaft cover (fig.1, b, fig. 2). The analog signal was then transmitted to the amplifier PCB 480E09, after that it was converted by the analog-to-digital converter NI USB-9215, recorded on a PC in a time dependent graph and then it was processed by means of the Fast Fourier Transform (FFT).

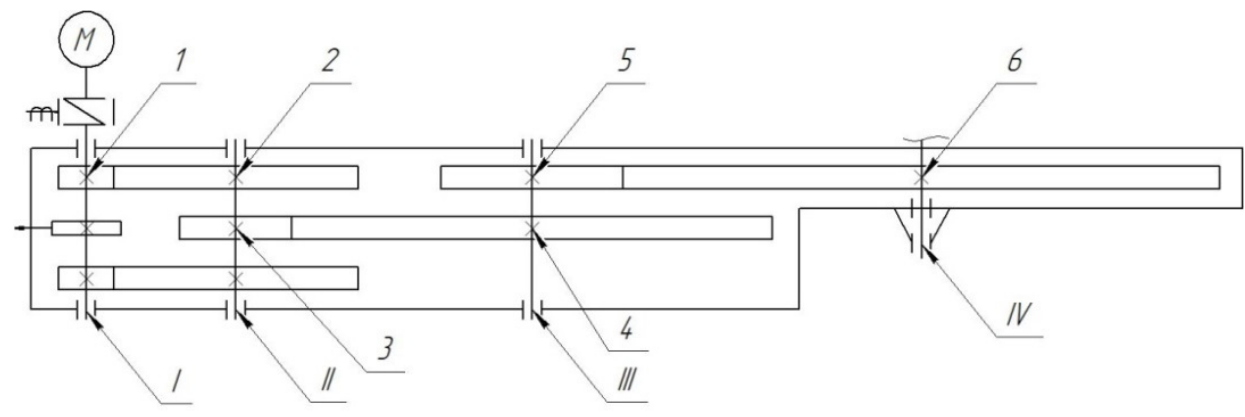

\begin{tabular}{|l|c|c|c|c|c|c|}
\hline Shaft No & / & \multicolumn{2}{|c|}{ /I } & \multicolumn{2}{|c|}{ III } & IV \\
\hline Gear No & 1 & 2 & 3 & 4 & 5 & 6 \\
\hline Number of teeth & 24 & 106 & 27 & 116 & 22 & 72 \\
\hline
\end{tabular}

Fig. 2. The kinematic scheme of ET-2 type gearbox of tunnel escalator drive

The results of the gearbox vibration state monitoring during specific operational time was used to obtain the information regarding the good (initial) and bad (faulty) state of the gearbox (fig. 3).

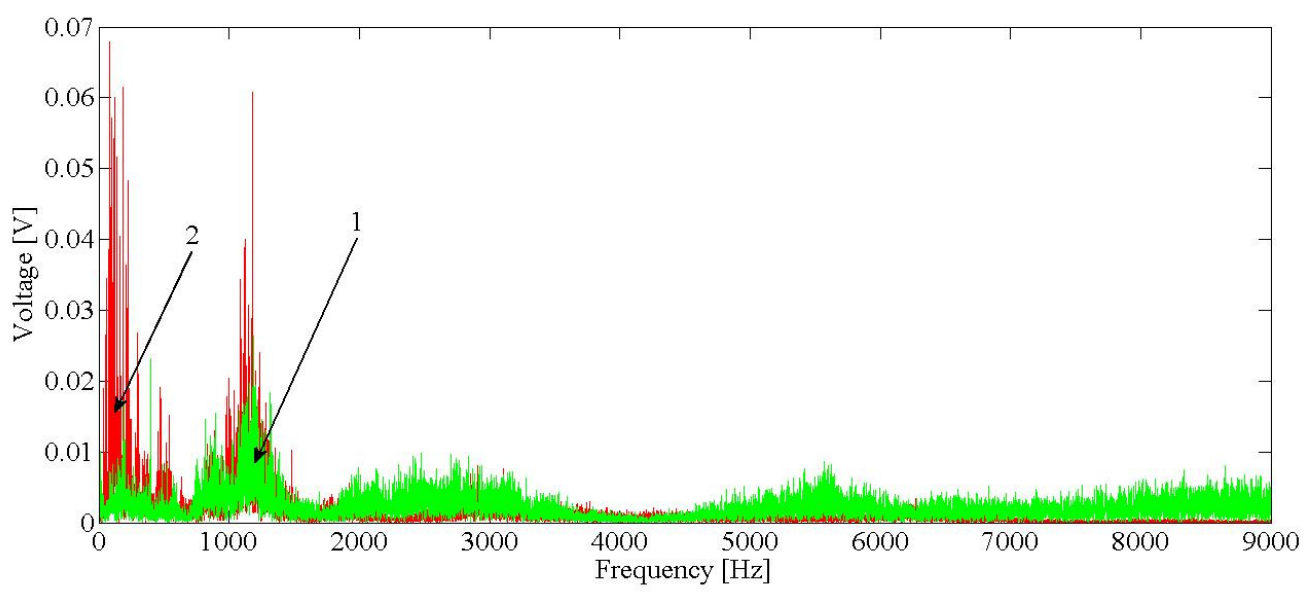

Fig. 3. Gearbox vibration spectra: 1 (green) - operable gearbox; 2 (red) - damaged gearbox

The averaged vibration spectra obtained by the fast Fourier transform (Fig. 3) do not allow to clearly identify the presence of defects at characteristic frequencies [6,7], but they allow to give a qualitative assessment of changes in the vibration state of the gearbox. Thus, the vibration spectrum of an operable gearbox (Fig. 3, spectrum 1 (green)) is characterized by a relatively low level with two zones of growth in vibrations in the low- and medium-frequency range. In the spectrum of the damaged gearbox (Fig. 3, spectrum 2 (red)), there is a significant increase in the amplitude of vibrations in the low-frequency zone, which, as the most important information, indicates the damage to the gears working surfaces [7]. The growth of "peaks" in the mid-frequency zone and humps of "white noise" in the highfrequency zone is evidence of flawed operation of the bearings and the development of bearing vibrations [6].

This is exactly what was confirmed during the gearbox repair works. Thus, after disassembly of the gearbox, a slight damage to the radial ball bearing located in the intermediate shaft cover (Fig. 1b) was found, as well as the significant damage to the gear surfaces of the high-speed coupling, which were present in the form of influxes and detachments. 
This information became the basis for identifying the causes of changes in the vibration state of the gearbox and justifying the frequency ranges of vibration levels monitoring to control its performance.

\section{Research method}

In the practice of machines technical state vibrodiagnostics, a procedure that is usually used comprises of comparing the spectrum of the vibration signal measured on the diagnosed equipment with the spectrum of the vibration signal measured previously on the same equipment, or on a certainly operable equipment with similar characteristics and modes of operation [13]. Therefore, as the first step, the vibration analysis of an operable gearbox is performed (Fig. 3, spectrum 1).

The time dependent vibration signal is converted to low or high resolution spectra using a fast Fourier transform procedure and two filtering techniques [14].

To obtain the low resolution spectrum, the first twenty blocks of data are cut off and the remaining data is filtered through a Flat top window. This ensures that the filtered signal amplitude corresponds to the initial one.

The Hann window is used to obtain the high resolution spectrum. The frequencies are more precisely determined.

The low resolution spectrum is used for the initial signal analysis and detection of high vibration bands, while the high resolution spectrum is used to determine the frequencies with the highest amplitudes in these bands more accurately.

Signal processing is performed in the DASYLab software environment, which, through graphical programming, allows you to quickly build a scheme for converting a digital signal (Fig. 4).

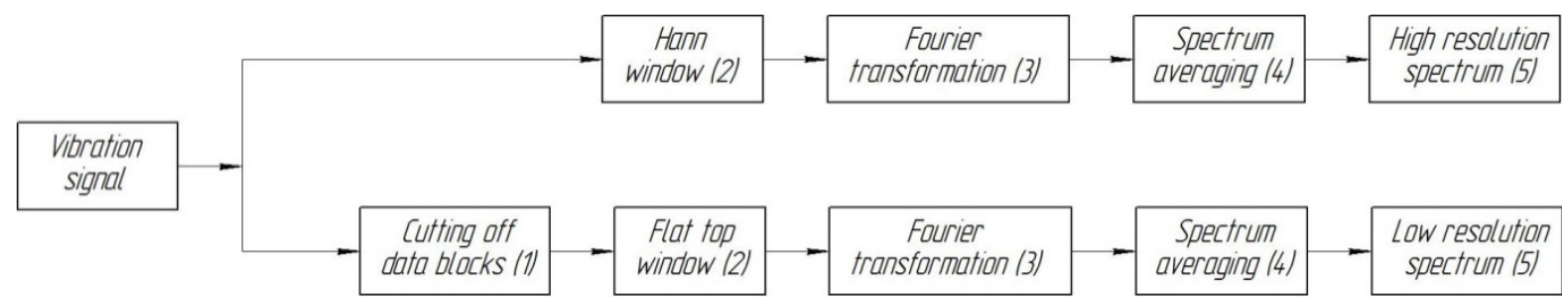

$a$

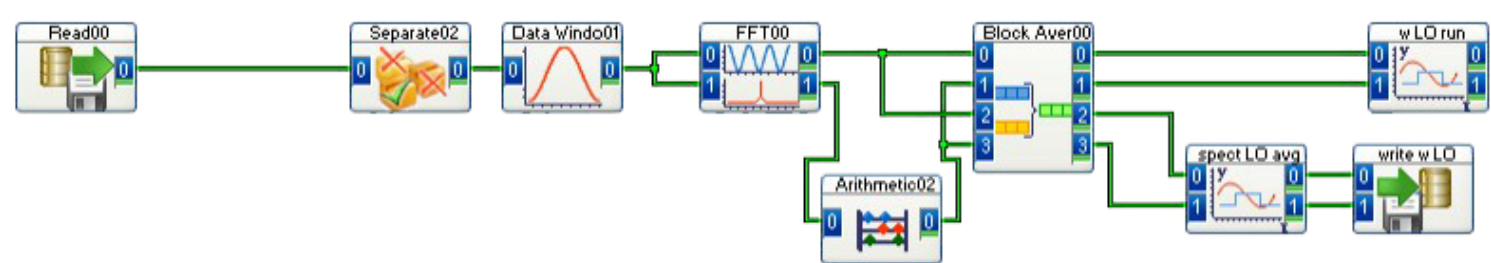

$b$

Fig. 4. Digital signal processing in DASYLab: a) block scheme for obtaining spectra of different resolutions;

b) an example of implementing a signal transformation into a low resolution spectrum

Signal filtering using the Hann window has been performed in order to distinguish frequencies of the most intense disturbances in range bellow $220 \mathrm{~Hz}$. Therefore, high resolution spectrum has been obtained which is shown on fig. 5.

The model spectrum of gearbox vibrations is determined by the measurements of the operable gearbox results [13].

The vibration spectrum of an operable gearbox is calculated by means of vibration signal of 200 sec. duration, measured in the axial direction by a vibration accelerometer mounted on the cover of the II (intermediate) shaft (Fig. 2).

A low resolution spectrum was obtained on the first step of the measured signal transformation, in which two bands with high vibration intensity were detected - from 74 to $200 \mathrm{~Hz}$ and from 1155 to $1210 \mathrm{~Hz}$, that can be observed on the non-filtered spectrum (Fig. 3, spectrum 1).

In order to isolate the frequencies of the most intense excitations in the range up to $220 \mathrm{~Hz}$, the filtering of the signal was carried out using Hann windows and the high resolution spectrum presented in Fig. 5.

\section{Analysis of the research results}

The analysis of the vibrations of the gearbox is performed with the frequencies of kinematic excitation generated by gears and rolling bearings [7], the main of which are: the rotation frequency of the $j$ - th shaft $\left(f_{r j}\right)$, the gear mesh 
frequency of the $i$ - th transmission $\left(f_{z i}=f_{r j} z_{j}\right)$, the inner $\left(f_{I R}\right)$ and outer $\left(f_{O R}\right)$ race frequencies, the ball spin frequency $\left(f_{B S}\right)$ and their multiples.

Analysis of the high resolution spectrum (Fig. 5) revealed the presence of a peak at the gear mesh frequency of the 2nd gear $f_{z 2 I}=74 \mathrm{~Hz}$. This indicates a possible malfunction of the gearing, which transmits movement from the intermediate shaft $I I$ to the low-speed shaft $I I I$ (Fig. 2). Vibrations peak at multiple frequencies $k \cdot f_{z 2 I}$, at $k=1,5 ; 2,5$. This indicates that there may be the variable stiffness defect of the meshed teeth. But at multiple frequencies, this defect is only present when resonance vibrations occur [6].

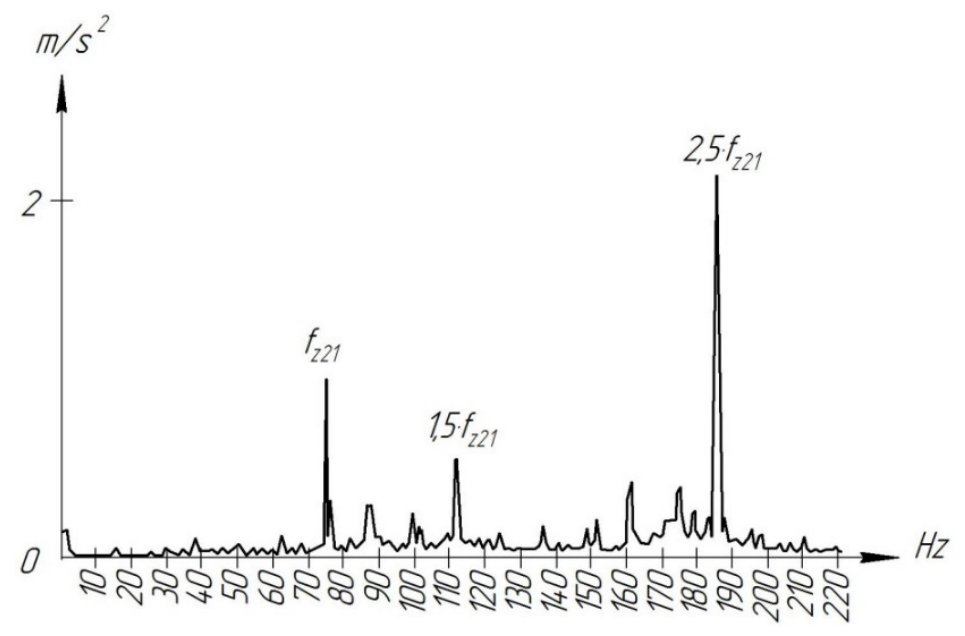

Fig. 5. High resolution spectrum in low frequency band up to $200 \mathrm{~Hz}$

To determine the natural frequencies of the gearbox elements, we use the Ansys software environment, to be accurate its Modal analyzer.

To do this, the mechanical characteristics of the material in the Engineering Data module are specified. Next, the Parasolid format 3D model is loaded into the module and the parts relationships are specified in the Connections module (Fig. 6). After that, a standard finite element (Mesh) breakdown takes place and model constraints are specified. In our case, the limitation is the need to represent the bearing units as elastic supports with a specific stiffness of $1,15 \cdot 10^{9} \mathrm{~N} / \mathrm{m}^{3}$. The simulation results of the first two modes of shaft oscillation are depicted on Fig. 7 .

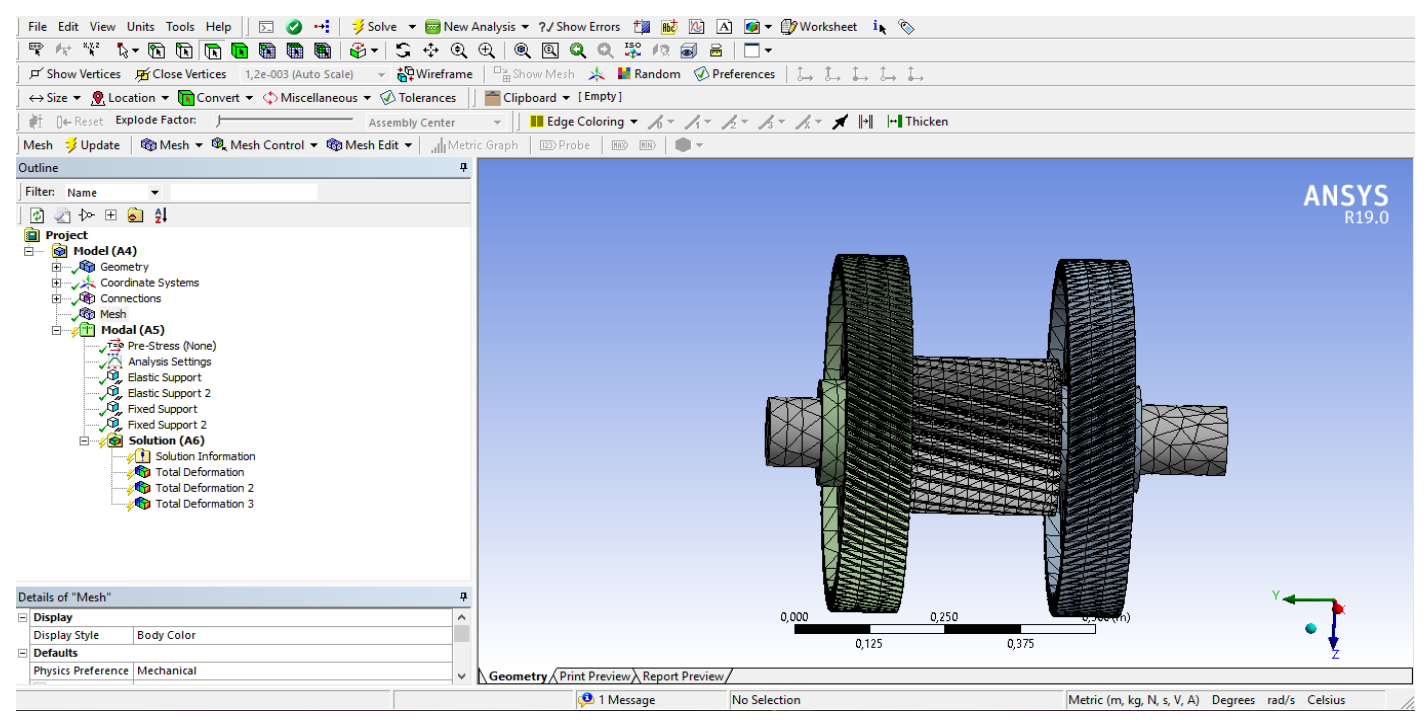

Fig. 6. Intermediate shaft model in Ansys Mechanical (Modal analyzer module window)

As can be seen (Fig. 7a), the first natural frequency of the intermediate shaft $(188 \mathrm{~Hz})$ is close to 2.5 times the harmonic of gear mesh frequency, which confirms the presence of a defect of variable teeth stiffness in the gearing, that transmits motion from the intermediate shaft $I I$ to the low-speed one $I I I$. 
The results indicate a variable teeth stiffness in the gearing $\left(z_{4} / z_{3}\right)$ and the presence of parametric resonance vibrations, which lead to the emergence of discontinuous shock modes of gearing operation and causes damage to the profile of the teeth [6].

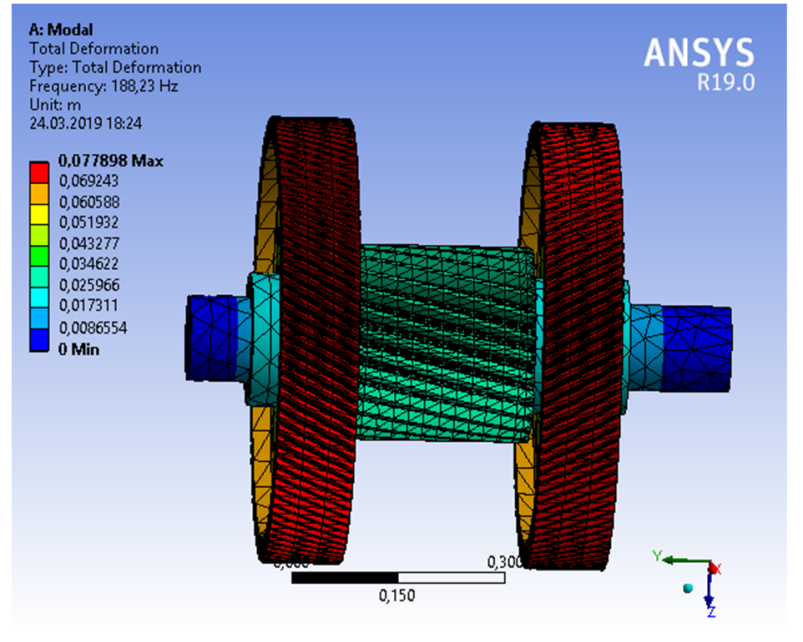

$a$

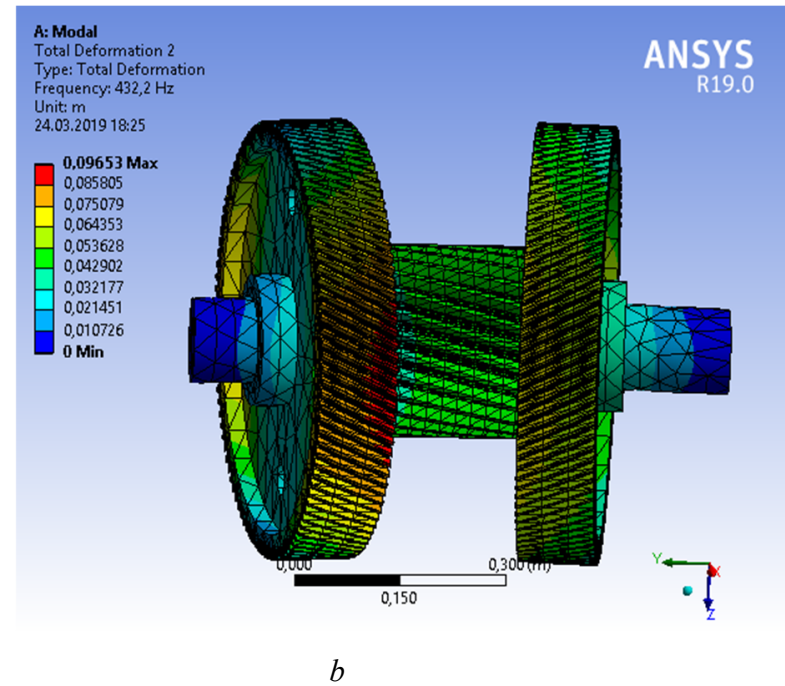

$b$

Fig. 7. First $a$ ) and second $b$ ) modes of intermediate shaft oscillations

The zone of high vibration intensity that lies in the range from 1155 to $1210 \mathrm{~Hz}$ (Fig. 3) may correspond the resonant vibrations of the intermediate shaft cover, where the damaged radial ball bearing of model 324 is installed (Fig. $1 b$ ) with the parameters: $d \times D=120 \times 260 \mathrm{~mm}, z=8, D_{w}=42.86 \mathrm{~mm}$ and a rotation frequency $n=165 \mathrm{~min}^{-1}$. In addition, a vibration accelerometer was installed on this cover.

When modelling the oscillation modes of the intermediate shaft cover in the Ansys software environment, it was assumed that it was elastically fastened to the housing at bolt hole locations with a specific stiffness of $2,64 \cdot 10^{17} \mathrm{~N} / \mathrm{m}^{3}$. The simulation results, which are the first two modes of shaft cover oscillation are presented in Fig. 8.

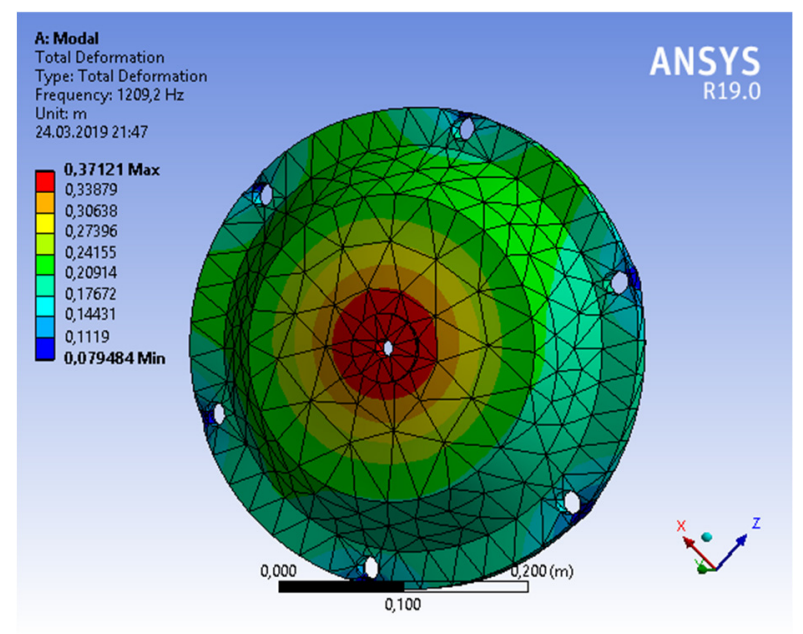

$a$

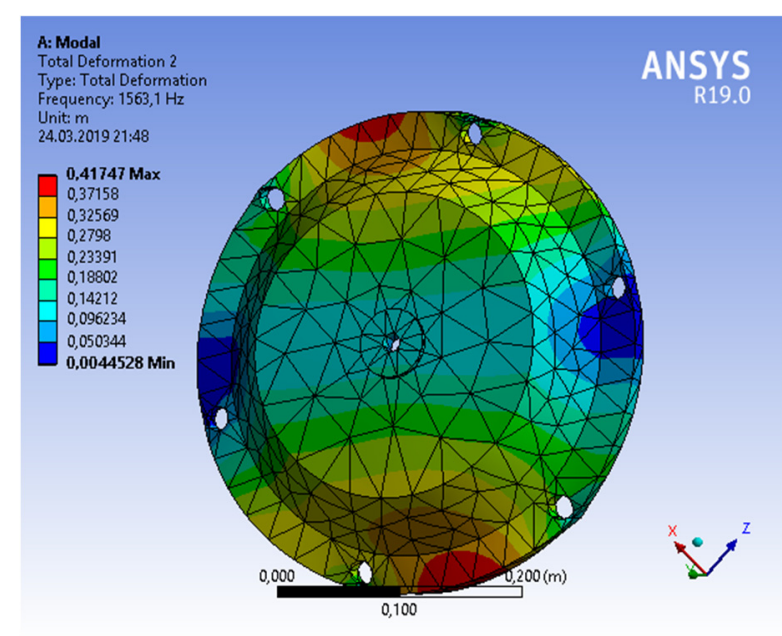

$b$

Fig. 8. First $a$ ) and second $b$ ) modes of intermediate shaft cover oscillation

First shaft cover natural frequency is $1208 \mathrm{~Hz}$ (Fig. 8, a), that affirms resonance nature of gearbox vibrations in the range from 1155 to $1210 \mathrm{~Hz}$ (Fig. 3), that caused by the defect in the bearing that is installed there. 


\section{Conclusions}

1. Obtaining and analyzing high resolution spectra in conjunction with the use of computer simulation method to determine the natural frequencies of individual elements of the gearbox of metro tunnel escalator drive definitely allows to diagnose gears defects of variable stiffness of the teeth type, which occur in the gearbox shafts local resonance areas.

2. The modes of oscillation analysis, that allows us to obtain cover's natural frequencies, of the shaft cover, on which the vibration accelerometer is installed, allows to diagnose the defect development in the bearings.

3. It is recommended, that vibrations measurements using developed method and control of the vibration levels near the frequencies, that correspond the first mode of natural vibrations of the gearbox intermediate shaft and its shaft cover, were included to the system of the technical state monitoring of the metro tunnel escalator drive gearbox of ET-2 type.

1. Методи вібраційної діагностики початкових стадій пошкодження обертових систем / І.М.Яворський, П.П. Драбич, І.Б. Кравець, І.Й. Мацько. // Фізико-хімічна механіка матеріалів, 2011. - № 2. - 134 с.

2. Ишин Н.Н, Гоман А.М., Скороходов А.С., Натурьева М.К. Оценка остаточного ресурса зубчатих передач в условиях эксплуатации // Неразрушающий контроль и диагностика. - 2014. - № 2. - С. 38-48.

3. Trivedi P., Bharti P.K. Study Of Bearing Rolling Element Defect Using Emperical Mode Decomposition Technique. International Journal of Engineering Development and Research (IJEDR). - 2017. - Vol. 5. No. 2. - P. 553-565.

4. Barszcz T., Sawalhi N. Fault detection enhancement in rolling element bearings using the minimum entropy deconvolution. Archieves of Acoustics. - 2012. - Vol. 37, No. 2. - P. 131-141.

5. Barzdaitis V., Zemaitis V., Zebelys K., Pocius Z., and Mazeika P. Condition monitoring of roller bearings using different diagnostic methods. Diagnostyka, - 2004. - Vol. 30, № 1. - P. 53-60.

6. Неразрушающий контроль. Справочник в 7 томах под ред. В.В. Клюева. /Том 7. Книга 2. Вибродиагностика. М.: Машиностроение, 2005. - 829 с.

7. Диагностические признаки и виды дефектов промышленного оборудования [Електронний ресурс] - Режим доступу до ресурсу: http://baltech.com.ua/catalog.php?catalog=166

8. Jamaludin, N., Mba, D., Bannister, R. H. Condition monitoring of slow-speed rolling element bearings using stress waves. Proceedings of the Institution of Mechanical Engineers, Part E: Journal of Process Mechanical Engineering. - 2001. Vol. 215, No. 4. - P. 245-271.

9. Автоматизация физических исследований и эксперимента: компьютерные измерения и виртуальные приборы на основе LabVIEW 7 / под ред. Бутырина П.А. - М.: ДМК Пресс, 2005. - 264 с. [Електронний ресурс] - Режим доступу до ресурсу: http://physicsbooks.narod.ru/Other/LabVIEW_7.pdf

10. Курбатов А. Программное обеспечение для сбора и обработки данных при измерениях и испытаниях // Компоненты и технологии, 2001. No.1. [Електронний ресурс] - Режим доступу до pecypcy: https://www.kite.ru/articles/measure/2001_01_68.php

11. Режим доступу до ресурсу: https://www.fresher.ru/2013/02/05/kak-remontiruyut-eskalator-v-metro/

12. Инструкция по техническому обслуживанию эскалаторов типов ЭТ-2, ЭТ-3, ЭТ-4 - Москва: Транспорт, 1987. $169 \mathrm{c}$.

13. Руссов, В.А. Диагностика дефектов вращающегося оборудования по вибрационным сигналам. Пермь, $2012 .-252$ с. Режим доступу до ресурсу doi: www.vibrocenter.ru/book.htm

14. Спектральный анализ на ограниченном интервале времени. Оконные функции. http://www.dsplib.ru/content/win/win.html

\section{Методика оцінки технічного стану редуктора приводу ескалатора метрополітену}

\section{Ю. М. Данильченко, В. Ю. Бойко, А. І. Петришин}

Анотація. На основі експериментального дослідження динамічних характеристик редуктора приводу ескалатора метрополітену у справному та пошкодженому станах розроблено методику виявлення збурень, щзо призводять до пошкодження робочих поверхонь зубчастих коліс і підиипників. Методика базується на отриманні та аналізі спектрів низької та високої роздільної здатності. Методика апробована на аналізі спектрів вібрацій стандартного трьохступеневого, чотирьохвалового редуктора приводу тунельного ескалатора. Аналіз вібрачій проводився за частотами кінематичного збурення, генерованого зубчастими передачами $і$ підиипниками кочення в зонах резонансних коливань елементів редуктора. За результатами аналізу встановлено наявність змінної жорсткості зубців у одного з зачеплень та пошкодження внутрішнього кільия кулькового підиипника кришки проміжного валу. 
Ключові слова: редуктор, спектр вібрачії, діагностика пошкоджень, DASYLab, спектри низької $і$ високої роздільної здатності, власні частоти, форми коливань

\section{Методика оценки технического состояния редуктора привода эскалатора метрополитена}

\section{Ю. М. Данильченко, В. Ю. Бойко, А. И. Петришин}

Аннотация. На основании экспериментального исследования динамических характеристик редуктора привода эскалатора метрополитена в исправном и поврежденном состояниях разработана методика определения возмущений, которые приводят к повреждениям рабочих поверхностей зубчатых колес и подиипников. Методика базируется на получении и анализе спектров низкой и высокой разрешающей способности. Методика апробирована на анализе спектров вибраций стандартного трёхступенчатого, четырёх-валового редуктора привода туннельного эскалатора. Анализ вибраций проводился по частотах кинематического возмущения, сгенерированного зубчатыми передачами и подиипниками качения в зонах резонансных колебаний элементов редуктора. По результатах анализа установлено наличие сменной жесткости зубиов в одном из зачеплений и повреждения внутреннего кольца шарикоподиипника крышки промежуточного вала.

Ключевые слова: редуктор, спектр вибрации, диагностика повреждений, DASYLab, спектры низкой и высокой разрешающей способности, собственные частоты, формы колебаний

\section{References}

1. Yavorsky, I.M., Drabich, P.P., Kravets, I.B. and Matsko, I.J. (2011), Metody vibracijnoji diaghnostyky pochatkovykh stadij poshkodzhennja obertovykh system [Methods of vibration diagnostics of the initial stages of damage of rotary systems], Physic-chemical material mechanics, no. 2.

2. Ishin, N.N, Goman, A.M., Skorokhodov, A.S. and Natur'eva, M.K. (2014), "Estimation of the residual life of gears under operating conditions", Nerazrushayushchii kontrol' i diagnostika, no. 2, pp. 38-48.

3. Trivedi, P. and Bharti, P.K. (2017), "Study Of Bearing Rolling Element Defect Using Emperical Mode Decomposition Technique", International Journal of Engineering Development and Research (IJEDR), vol. 5, no. 2, pp. 553-565.

4. Barszcz, T. and Sawalhi, N. (2012), "Fault detection enhancement in rolling element bearings using the minimum entropy deconvolution", Archieves of Acoustics, vol. 37, no. 2, pp. 131-141.

5. Barzdaitis V., Zemaitis V., Zebelys K., Pocius Z., and Mazeika P. (2004), "Condition monitoring of roller bearings using different diagnostic methods", Diagnostyka, vol. 30, no. 1, pp. 53-60.

6. Klyuev, V.V. (ed.). (2005), Nerazrushayushchii kontrol' [Non-destructive testing], Vibrodiagnostika, vol. 7, no. 2, Mashinostroenie, Moscow, Russia.

7. Diagnosticheskie priznaki i vidy defektov promyshlennogo oborudovaniya [Diagnostic markers and types of defects of the industrial equipment], http://baltech.com.ua/catalog.php?catalog=166

8. Jamaludin, N., Mba, D. and Bannister, R.H. (2001), "Condition monitoring of slow-speed rolling element bearings using stress waves", Proceedings of the Institution of Mechanical Engineers, Part E, Journal of Process Mechanical Engineering, vol. 215, no. 4, pp. 245-271.

9. Butyrina, P.A. (ed.) (2005), Avtomatizatsiya fizicheskikh issledovanii i eksperimenta: komp'yuternye izmereniya i virtual'nye pribory na osnove LabVIEW 7 [Automation of physical research and experiment: computer measurements and virtual devices based on LabVIEW 7], DMK Press, Moscow, http://physicsbooks.narod.ru/Other/LabVIEW_7.pdf

10. Kurbatov, A. (2001), "Software for data collection and processing during measurements and tests", Komponenty $i$ tekhnologii, no. 1, https://www.kit-e.ru/articles/measure/2001_01_68.php

11. Available at: https://www.fresher.ru/2013/02/05/kak-remontiruyut-eskalator-v-metro/

12. Instruktsiya po tekhnicheskomu obsluzhivaniyu eskalatorov tipov ЭТ-2, ЭТ-3, ЭТ-4 (1987), [Maintenance instruction for escalators of types ЭТ-2, ЭТ-3, ЭТ-4], Transport, Moscow, Russia.

13. Russov, V.A. (2012), Diagnostika defektov vrashchayushchegosya oborudovaniya po vibratsionnym signalam [Diagnostics of defects in rotating equipment with vibration signals], Perm, Russia, doi: www.vibrocenter.ru/book.htm

14. Spektral'nyi analiz na ogranichennom intervale vremeni. Okonnye funktsii [Spectral analysis over a limited time interval. Window functions], available at: http://www.dsplib.ru/content/win/win.html 